\title{
INTEGRATED ENERGY SIMULATION FOR BUILDING AND MEP SYSTEMS IN CONSIDERATION OF THE CHARACTERISTICS OF THERMAL ENERGY MEDIA FOR THERMAL CASCADING SYSTEMS
}

熱媒の特性を考慮した熱の多段階利用を含む建築外皮と躯体，設備機器の統合的連成計算

\author{
Ryota KUZUKI*, Makoto SATOH**, Takashi AKIMOTO***, \\ Shuzo MURAKAMI****, Hisaya ISHINO*****, Kenichi SASAJIMA*****, \\ Fumio NOHARA******, Hiroshi NINOMIYA******* and Yasuhiro TABATA******* \\ 工月良太，佐藤 誠，秋元孝之，村上周三，石野久彌， \\ 笹嶋 賢一，野原文男，二宮博史，田端 康 宏
}

This research focuses on the evaluation of thermal energy efficiency in a building including thermal cascading systems such as cogeneration, solar-thermal, and PV systems, combined with final energy consumption for space heating and cooling, a dehumidifier, and a water heater. The thermal energy efficiency of the whole system varies depending on not only calorific balances but also on the temperature of heat conveying media and its flow-rate to each consumption unit. Based on the concept of the simulation tools, the major development work involves the modeling of cogeneration units.

As the first development phase, a sample system consisting of one unit of each form of equipment has been completed adopting the "forward method." This paper describes the overview of the method by showing some results for a sample case study.

\section{Keywords: Integrated energy simulation, Cogeneration, Forward method, Thermal energy balance, Partial load performance} 統合エネルギーシミュレーション, コージェネレーション, 前進法, 熱収支, 部分負荷性能

\section{Introduction}

Carbon emissions reduction in the commercial and residential sectors is an urgent requirement, and there is a particular need for action on the demand side to make more efficient use of energy in the building sector, where energy consumption is rising markedly. In order to exploit the potential of supplied energy to the full, multistage use through onsite conversion to heat and electric power ought to be pursued. As a concrete method to realize this goal, cogeneration systems are expected to promote and expand.

Cogeneration systems are, along with solar power generation, designated "efficiency improving" technologies. They work by simultaneously generating electricity onsite to power machinery, lighting, and so on. They use the heat generated in the process for purposes such as air conditioning and water heating, thus raising the efficiency of primary energy use.

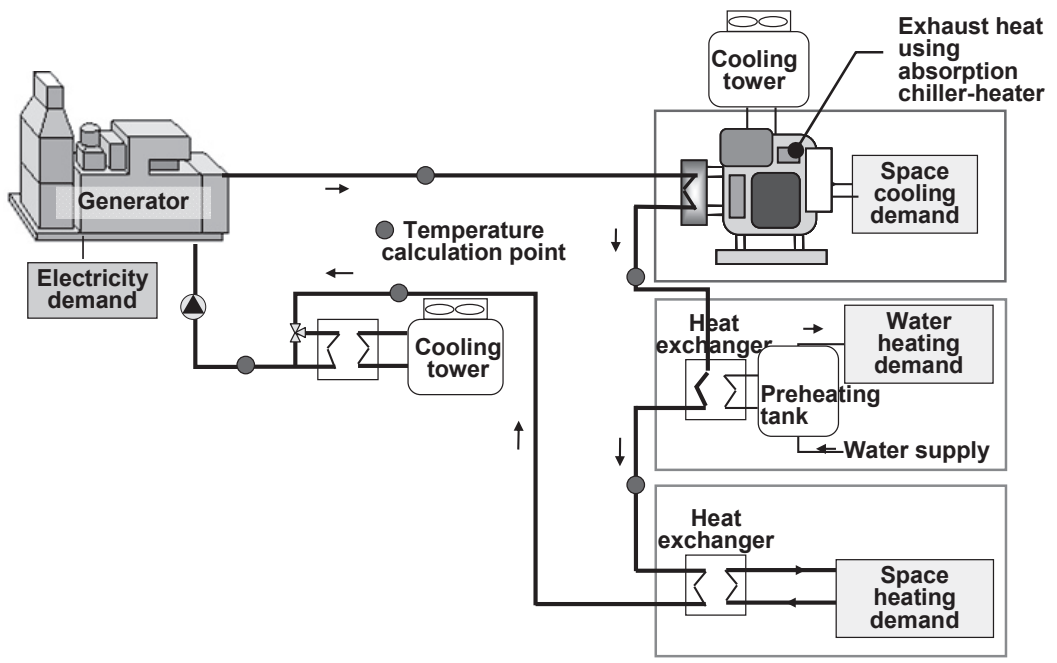

Fig. 1 Example of cogeneration system configuration

\footnotetext{
* Tokyo Gas Co., Ltd., Dr. Eng.

** Satoh Energy Research Co., Ltd., Dr. Eng.

*** Prof., Shibaura Institute of Technology

**** President, Building Research Institute

***** Emeritus Prof., Tokyo Metropolitan Univ.

****** Nihon Sekkei Co., Ltd.

******* Nikken Sekkei Co., Ltd.
}

東京ガス(知) 博十(叭学)

佐藤エネルギーリサーチ侏) 工博

芝浦工業大学 教授・工博

独立行政法人建築研究所 理事長. 工博

首都大学東京 名誉教授. 工博

日本設計株)

日建設計(株) 
Unlike most high-efficiency equipment, the performance of cogeneration systems is affected by the balance of electricity demand and heating/cooling demand, as well as by the timing of such demand. Assessing the effects quantitatively necessitates coupled calculation with all heat and electricity demand, including buildings, air conditioning, electrical equipment, and sanitation facilities.

One simulation program that enables such calculations to be made is the Building Energy Simulation Tool (BEST) now under development in Japan, with the initiative of Ministry of Land, Infrastructure, Transport and Tourism, which handles housings and facilities in an integrated manner in order to assess the energy performance of buildings as a whole. ${ }^{2}$ In view of the above background, the purpose of this study is to present a simulation logic for cogeneration systems that makes possible coupled calculation with each category of demand (building/air conditioning, electricity, and sanitation)

\section{Difference of simulation logic between BEST and the existing program - CASCADE III}

To serve as a point of reference before proceeding with this study, below we describe the algorithms used by existing simulation programs "CASCADE III".

This is a cogeneration system design and assessment program published by SHASE in 1995. Equipment load is derived from the electricity and heat energy balance in order to calculate annual energy consumption.

As the purpose of this study is to develop a simulation logic for incorporation into BEST, as described above, a departure must be made from the CASCADE III approach in that the heat balance must be expressed based on the flow rate and temperature difference of the heat medium (water), and calculations must be performable at rapid intervals of around five minutes. Table 1 shows a comparison of the principal specifications of each approach.

Table 1 Comparison of the specifications between CASADEIII and BEST

\begin{tabular}{|l|l|l|}
\hline \multicolumn{1}{|c|}{ Item } & \multicolumn{1}{|c|}{$\begin{array}{c}\text { Current CASCADE III } \\
\text { specifications }\end{array}$} & \multicolumn{1}{|c|}{$\begin{array}{c}\text { Required specifications for } \\
\text { BEST (suggested) }\end{array}$} \\
\hline Calculation time interval & 1 hour & Variable between 1 - 10 minutes \\
\hline Exhaust heat output & $\begin{array}{l}\text {-Calculation of the balance } \\
\text { of the amount of heat } \\
\text {-No distinctions between } \\
\text { heated water, steam, and } \\
\text { exhaust gas }\end{array}$ & $\begin{array}{l}\text { Calculated from temperature } \\
\text { difference of heat medium and } \\
\text { balance of flow rates }\end{array}$ \\
\hline $\begin{array}{l}\text { Exhaust heat } \\
\text { temperature }\end{array}$ & Fixed & Load following \\
\hline $\begin{array}{l}\text { Preheating tank/pipe } \\
\text { temperature }\end{array}$ & No change over time & $\begin{array}{l}\text { Load following (variable over } \\
\text { time) }\end{array}$ \\
\hline $\begin{array}{l}\text { Handling of mixed heat } \\
\text { sources }\end{array}$ & $\begin{array}{l}\text { Mixed use with gas-fired } \\
\text { absorption chiller-heater and } \\
\text { boiler possible }\end{array}$ & $\begin{array}{l}\text { Possible linkage with other heat } \\
\text { sources (e.g., electric chillers) } \\
\text { as well as equipment in left } \\
\text { column }\end{array}$ \\
\hline $\begin{array}{l}\text { Handling of multiple heat } \\
\text { sources and generators }\end{array}$ & $\begin{array}{l}\text { Treated as a single unit by } \\
\text { aggregating the capacities of } \\
\text { each }\end{array}$ & $\begin{array}{l}\text { Capable of allocating operating } \\
\text { hours individually where } \\
\text { multiple units are split up }\end{array}$ \\
\hline
\end{tabular}

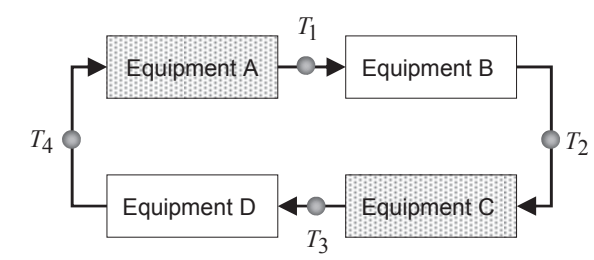
pipes tanks

No heat capacity

\section{$T_{i}^{*}$ :Temperature} at time step prior to

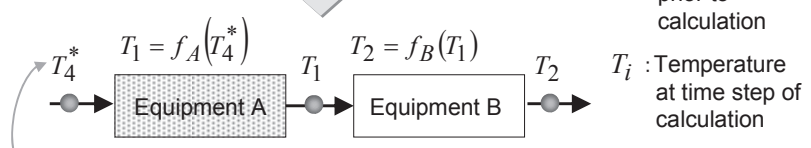

Temperature difference absorbed into downstream heat capacity

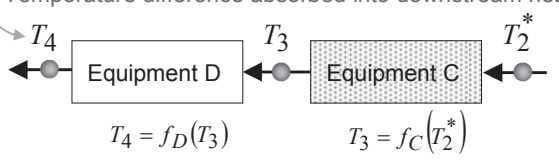

Fig.2 Basic algorithm

The basic approach adopted for this study is the forward method, based on Nagai et.al ${ }^{2}$. As Fig.2 shows, calculations are conducted using the inlet temperature at the previous time for equipment with heat capacity (pipes and the preheating tank) which can be assumed stable for 10 minutes at longest. And the outlet temperature of upstream equipment at the current time in the case of equipment for which heat capacity is disregarded (all equipment apart from pipes and the preheating tank). Even at starting time of equipments, the same approach is adopted by calculating temperature of pipes and tanks during the equipments being out of work.

\section{Modeling of cogeneration system}

The components of the model considered in this study are shown in Fig.1. As the BEST algorithm allows flexible connection of modules such as

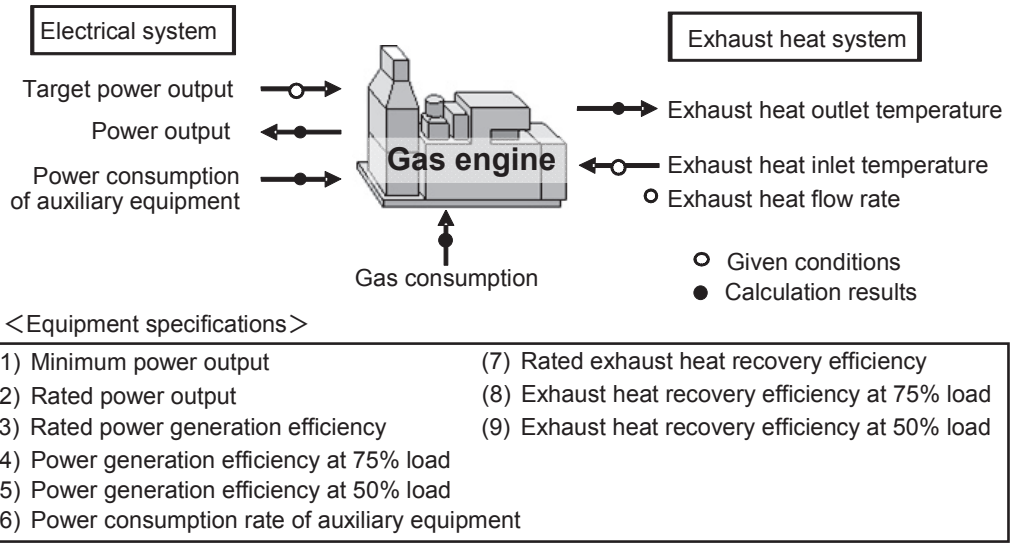

$<$ Inputs $>$

(1) Target power output (3) Exhaust heat inlet temperature

(2) Exhaust heat flow rate

$<$ Outputs>

\begin{tabular}{|ll}
\hline (1) Power output & (4) Exhaust heat outlet temperature \\
(2) Gas consumption & (5) Power consumption of auxiliary equipment \\
(3) Exhaust heat recovery & \\
\hline
\end{tabular}

Fig.3 Input and output parameters of gas engine 
equipment, controllers, and boundary conditions, systems are basically freely configurable. The system considered in this study consisted of a generator, systems that utilize exhaust heat (space cooling, space heating, and water heating), a surplus exhaust heat radiator, auxiliary equipment, pipes with heat capacity and a controller. Pipes with heat capacity provide temperature at the previous time as described above.

\section{(1) Generator}

A model was developed using a gas engine and a gas turbine for the generator. As one example, Fig. 3 shows the input and output parameters for the gas engine. The equipment specifications consisted of those typically found in catalogs and engineering data. As partial load efficiency at two representative points is inputted along with rated efficiency, the partial load characteristic curve of these three points is interpolated by quadratic equation when a simulation is actually performed. For this study, the characteristic expression for partial loads was developed as a quadratic curve as shown in Fig. 4 based on the numeric values for power generation efficiency at three points according to the literature ${ }^{3}$ (at $75 \%$ and $50 \%$ of rated load). The minimum partial load is determined by cases. If the available partial load is less than $50 \%$, the characteristic curve is extrapolated. Gas consumption and exhaust heat utilization were found according to power output.
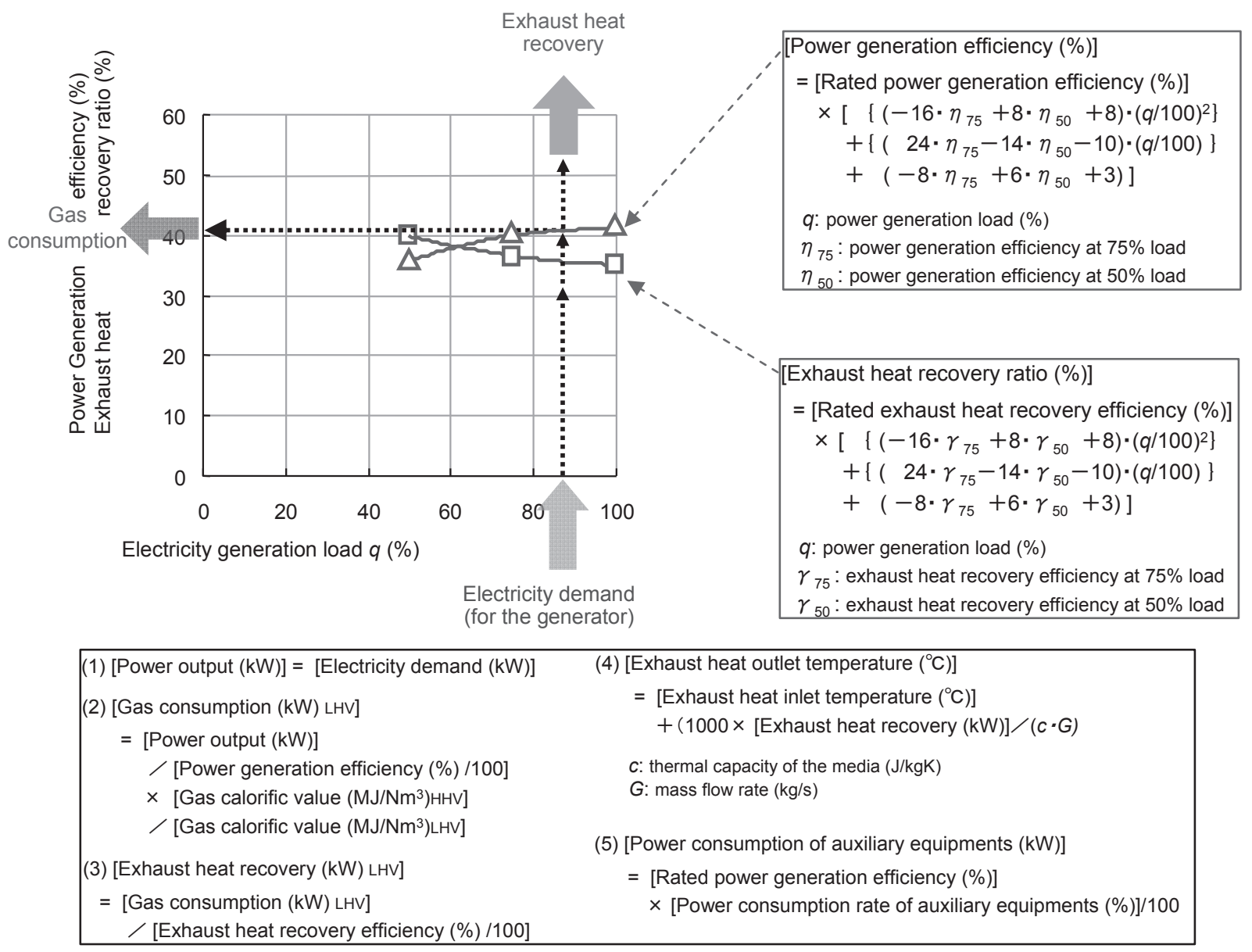

Fig. 4 Modeling of partial load characteristics of gas engine

Almost the same model was used for the gas turbine, except that the increase in power generation output as outside air temperature rises was taken into account. With the exception of the modeling of dynamic characteristics, this model may also be applied to a phosphoric acid fuel cell following the same logic used for a gas engine.

\section{(2) Controller}

In addition to the generator controller, a multi-unit controller capable of master control of multiple generators was developed.

Fig. 5 and Fig. 6 show in overview how control of the gas engine generator works. The controller have the current time ach the electricity demand at the time, a control signal is sent to the generator being controlled to indicate that target power output should equal the rated power output of the generator concerned. In the case of "generated electricity usage design", in other word electricity load following, target power output is obtained by the logic shown in Fig. 4 and a control signal is sent to the controlled generator. 
An example of control by means of a multi-unit controller is shown in Fig. 7, which is for a multi-unit system consisting of four $1,000 \mathrm{~kW}$ generators. This shows the output of each generator to meet power demand where the first unit is operated at fixed output and subsequent units are operated on a load-following basis with a minimum output of $600 \mathrm{~kW}$. For the "Purchased" part load in the Fig. 7, because the load is less than the minimum load of a gas engine, grid power is supplementary supplied by grid power.

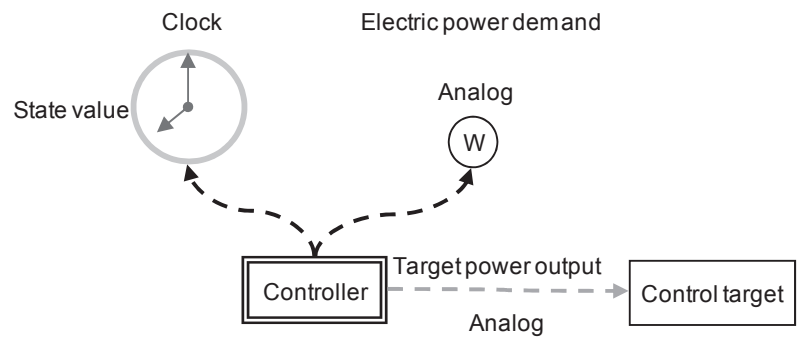

Fig. 5 Role of generator controller

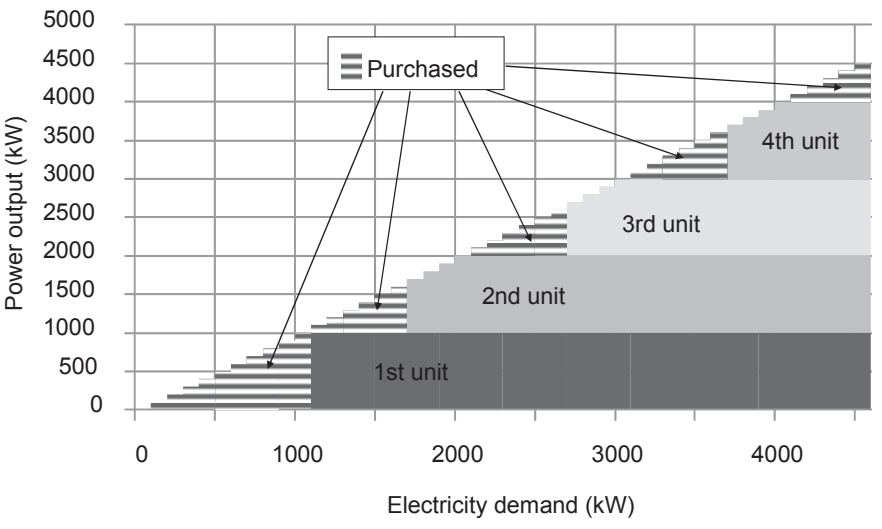

Fig. 7 Example of multi-unit generator controller
Current time

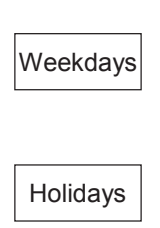

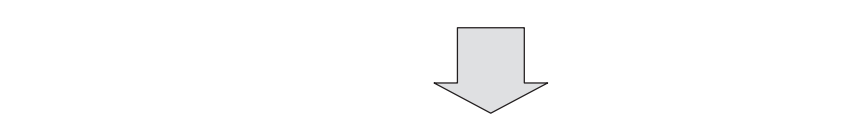

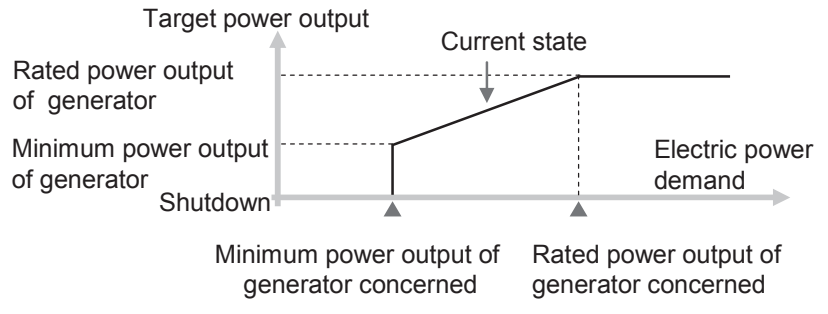

Fig. 6 Method of controlling target output of generator

\section{(3) Waste heat using absorption chiller-heater}

The input and output parameters of the waste heat using absorption chiller-heater are as shown in Fig. 8 and Fig. 9 . In this study, only those types that use exhaust heat from heated water were considered.

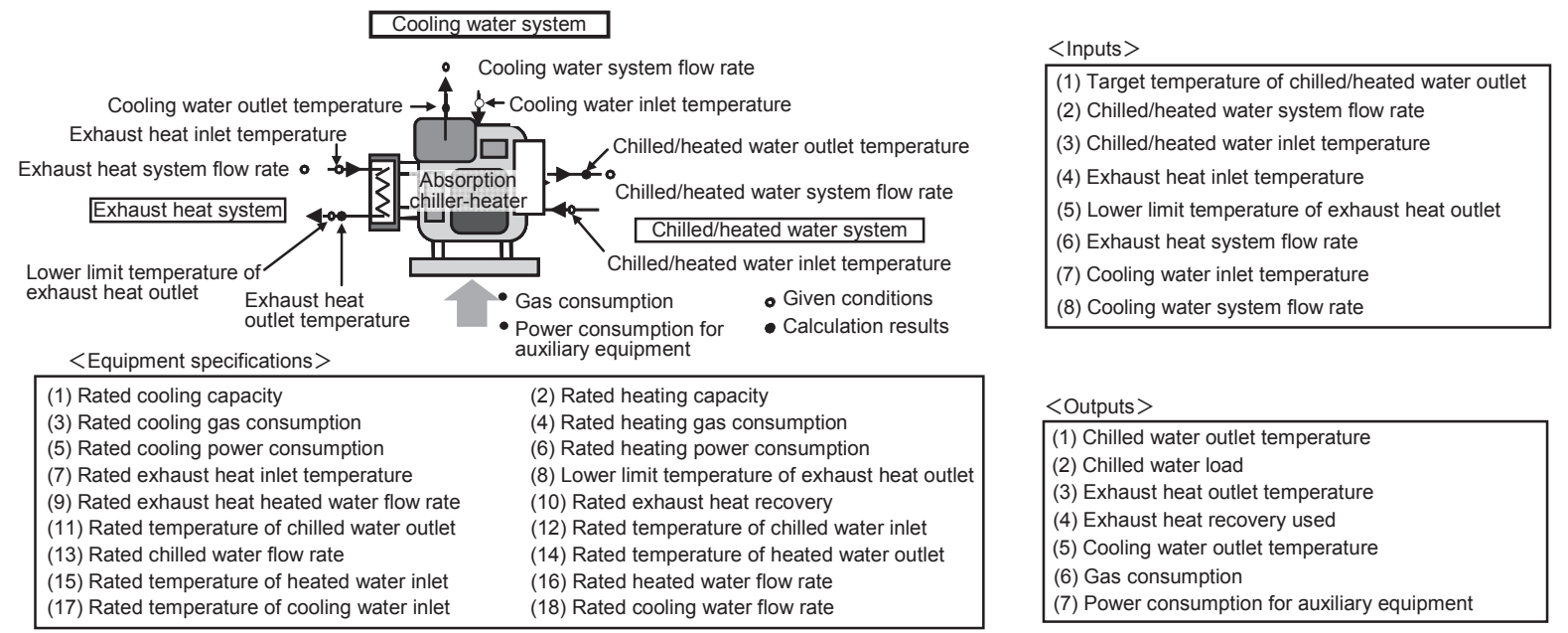

Fig. 8 Input and output parameters of waste heat using absorption chiller-heater

Fig.10 shows parameters used for each calculation step. The flow rate of chilled water is determined by the controller depending on the demand for cooling, and exhaust heat recovery is calculated according to this demand and exhaust heat potential (exhaust heat inlet temperature and exhaust heat flow rate). Given exhaust heat recovery, it is possible to calculate the gas consumption and outlet temperature of each system.

Exhaust heat recovery is calculated by first calculating recoverable exhaust heat from the inlet temperature and flow rate of each system, based on which the 
which the exhaust heat outlet temperatures are checked and ultimate exhaust heat recovery is calculated. Gas consumption is obtained by deducting exhaust heat utilization from gas consumed during operation as a direct-fired absorption chiller-heater without utilizing exhaust heat.

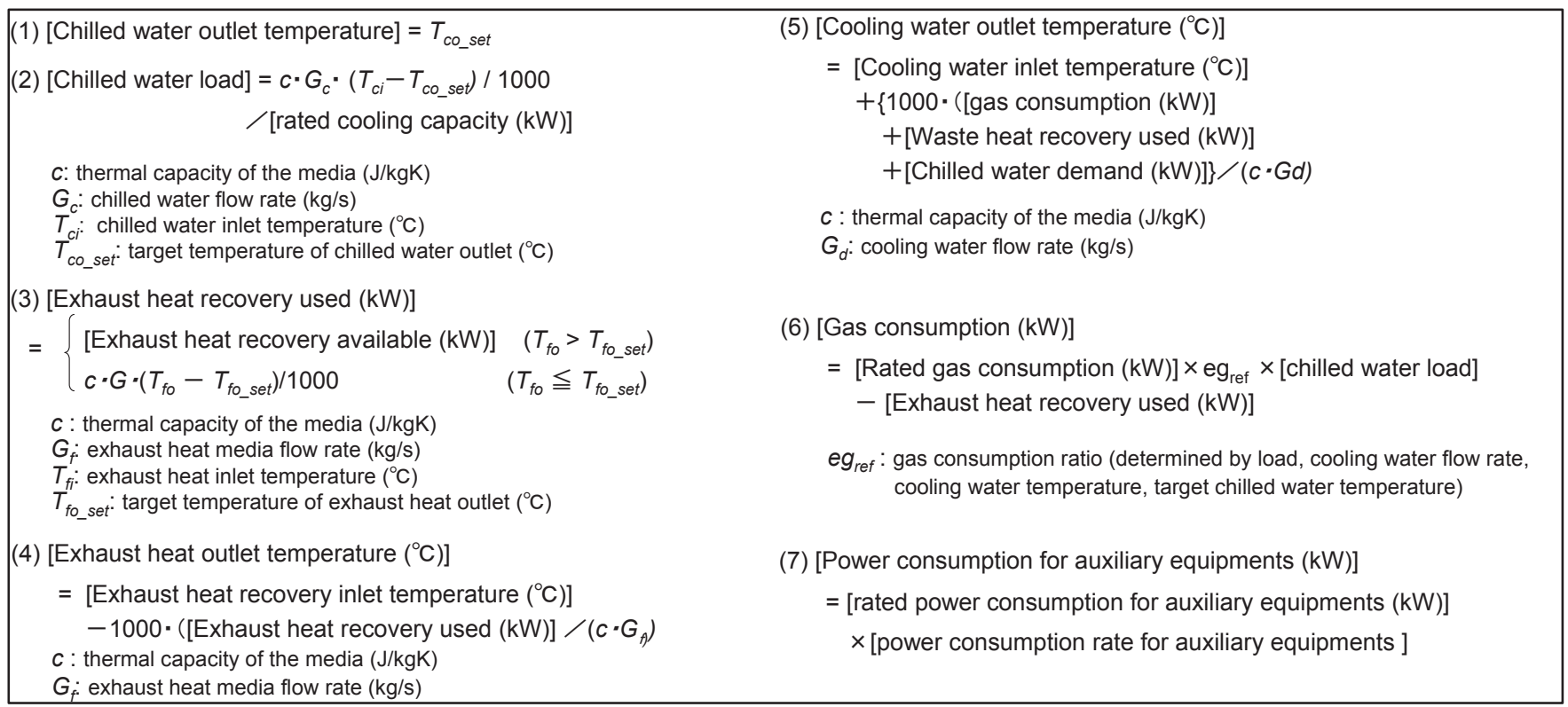

Fig. 9 Modeling of characteristics of exhaust heat using absorption chiller/heater

The exhaust heat recovery of absorption chiller-heaters varies according to load factor, exhaust heat temperature, and exhaust heat flow rate. As Fig.11 shows, the equipment characteristics are replicated so that chilled water is generated using exhaust heat alone when operating at a load below a certain level. However, when the load factor rises and demand for chilled water can no longer be met by inputting exhaust heat alone, exhaust heat input is lowered and supplementation by gas is gradually increased. Thermal consumption is determined by the characteristic curves with the slope of 1/COP. The slope of the curve changes at the middle load over which the gas fired thermal supplement is required. In general, the COP of gas fired absorption is higher than that using waste heat recovery, therefore the slope $(1 / \mathrm{COP})$ changes at a certain load.
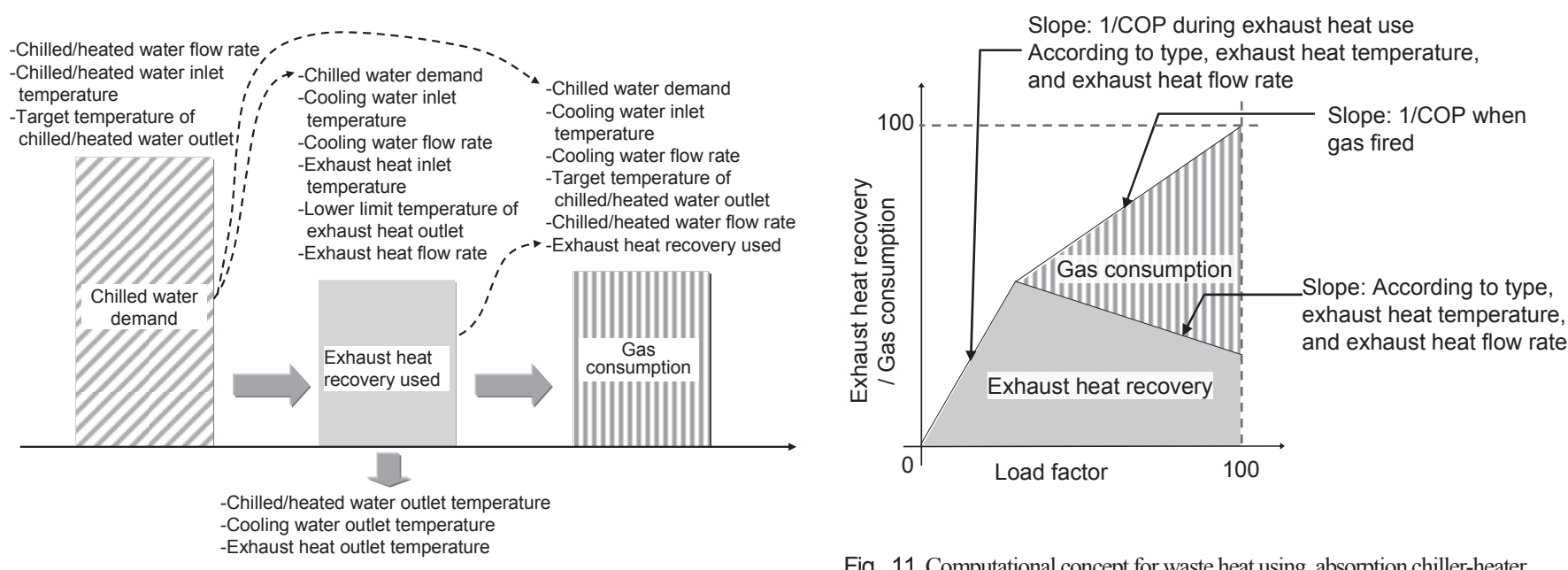

Fig. 10 Parameters in each calculation step for a waste heat using gas absorption chiller

\section{Coupled calculation}

In this section, we describe a simulation performed for the sample system.

In this case, the simulation was performed under the following conditions and for the case shown in Table 2. Heat and power demands (space cooling, space heating, and electricity) were modeled using CASCADE III and load data created at five-minute intervals. 
The secondary air-conditioning system was excluded from calculations.

The heat exchanger was modeled by varying heat transfer availability according to flow rate. Calculations were made for typical days (weekdays and holidays) each month.

\section{(1) Simulation settings}

The simulation was performed using the settings shown in Table 2. A cogeneration system was adopted. A gas engine was employed for the generator and the exhaust heat of heated water having a temperature of approximately $90 \mathrm{degC}$ was used by an waste heat using absorption chiller-heater. Any surplus exhaust heat at this time is released into the atmosphere by a cooling tower.

\section{(2) Simulation results}

Fig.12 shows the results of the simulation for a typical summer's day in Japan. It can be seen that, as the gas engine was configured to operate on a loadfollowing basis, output varies each time. A tentative hunching seems to be influenced by the time lugs of PID control. As can be seen from the exhaust heat outlet/inlet temperatures of the gas engine, the simulation replicates the fall in the temperature of the pipes (which function as the system's heat carrier when shut down at night) to around outside air temperature and inflow of cooled exhaustheated water to the gas engine. The absorption chiller-heater is entirely direct gas-fired and makes no use of exhaust heat immediately after the gas engine starts up, as the temperature of the exhaust heat system is low. It can also be seen that the equipment characteristics are replicated so that exhaust heat utilization increases slightly and gas consumption falls when the amount of heat of chilled/heated water gradually declines from around 18:00.

Fig.13 shows an example of the heat balance per month through a year which helps the MEP designers to determine the capacity of the gas engine to adjust the available waste heat depending on the chilled/heating water demand. Fig. 14 shows the relationship between load factor and the efficiency of power generation capacity and exhaust heat recovery when the gas engine is in operation during two months (July and August) of the one-year simulation.

The Fig.14 includes power generation efficiency and exhaust heat recovery efficiency at the inputted rated load, $75 \%$ load, and $50 \%$ load, and it could be confirmed that the expected results were obtained by quadratic interpolation of efficiency at partial load for all power generation and exhaust heat recovery efficiency.

[Gas engine]
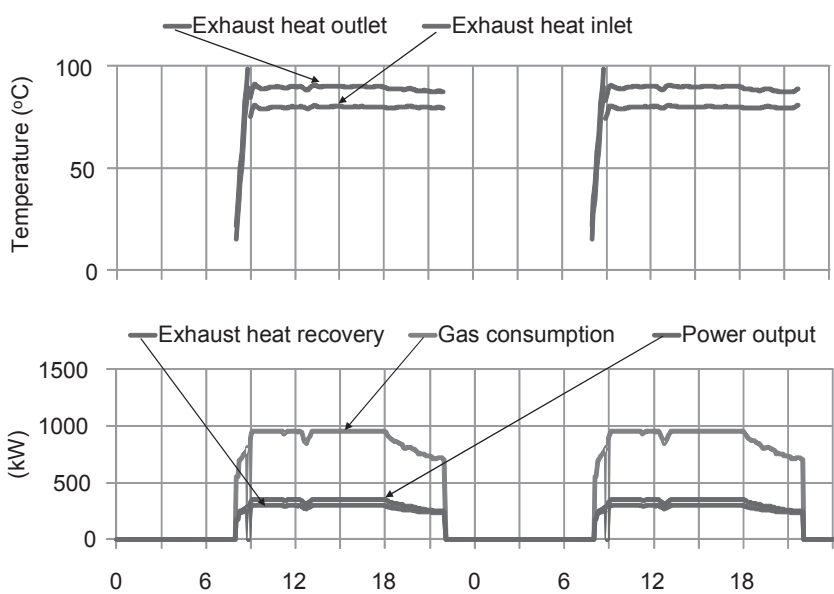

Table 2 Simulation settings

\begin{tabular}{|c|c|}
\hline Item & Setting \\
\hline \multirow[t]{2}{*}{ Overall } & Gas type: City gas $13 \mathrm{~A}$ \\
\hline & Heating value: $45 \mathrm{MJ} / \mathrm{m}^{3}$ (HHV) \\
\hline \multirow[t]{3}{*}{ Building } & Total floor area: $9,919 \mathrm{~m}^{2}$ (12 floors) \\
\hline & Ceiling height: $2.6 \mathrm{~m}$ \\
\hline & Zoning: 8 zones with air conditioner in each \\
\hline \multirow{2}{*}{$\begin{array}{l}\text { Operating } \\
\text { schedule }\end{array}$} & Operating hours: 08:00-22:00 (Monday-Friday) \\
\hline & $\begin{array}{l}\text { Heating/cooling periods: cooling (May- } \\
\text { November), heating (December-April) }\end{array}$ \\
\hline \multirow[t]{4}{*}{ Gas engine } & Rated power output: $350 \mathrm{~kW}$ \\
\hline & $\begin{array}{l}\text { Rated power generation efficiency/rated exhaust } \\
\text { heat recovery efficiency (LHV basis): } \\
40.5 \% / 34.5 \%\end{array}$ \\
\hline & Auxiliary equipment motive power: $17.5 \mathrm{~kW}$ \\
\hline & Control method: load following \\
\hline \multirow[t]{2}{*}{$\begin{array}{l}\text { Waste heat using } \\
\text { absorption } \\
\text { chiller-heater }\end{array}$} & $\begin{array}{l}\text { When cooling (rated capacity/gas consumption } \\
\text { (no exhaust heat)/power consumption/rated } \\
\text { exhaust heat recovery): } 1,055 / 822 / 5.1 / 326 \mathrm{~kW}\end{array}$ \\
\hline & $\begin{array}{l}\text { When heating (rated capacity/gas } \\
\text { consumption/power consumption): 692/822/4.8 } \\
\text { kW }\end{array}$ \\
\hline $\begin{array}{l}\text { Heat exchanger } \\
\text { for space heating }\end{array}$ & Capacity $298 \mathrm{~kW}$ \\
\hline \multirow[t]{5}{*}{ Pump } & $\begin{array}{l}\text { Chilled/heated water pump Flow rate: } 3,024 \\
\text { 1/min; power consumption: } 30 \mathrm{~kW}\end{array}$ \\
\hline & $\begin{array}{l}\text { Cooling water pump Flow rate: } 5,0001 / \mathrm{min} \text {; } \\
\text { power consumption: } 22 \mathrm{~kW}\end{array}$ \\
\hline & $\begin{array}{l}\text { Heated water pump Flow rate: } 8551 / \mathrm{min} \text {; } \\
\text { power consumption: } 11 \mathrm{~kW}\end{array}$ \\
\hline & $\begin{array}{l}\text { Exhaust heat circulating pump Flow rate: } 481.8 \\
\text { 1/min; power consumption: } 3.7 \mathrm{~kW}\end{array}$ \\
\hline & $\begin{array}{l}\text { Cooling water pump for exhaust heat cooling } \\
\text { Flow rate: } 963.61 / \mathrm{min} \text {; power consumption: } 7.5 \\
\mathrm{~kW}\end{array}$ \\
\hline \multirow[t]{2}{*}{ Cooling tower } & Cooling water flow rate: $5,0001 / \mathrm{min}$ \\
\hline & Fan: $16.5 \mathrm{~kW}$ \\
\hline $\begin{array}{l}\text { Three-way valve } \\
\text { control of cooling } \\
\text { water }\end{array}$ & $\begin{array}{l}\text { PID control according to flow ratio of cooling } \\
\text { water three-way valve to attain target preset } \\
\text { temperature observing the cooling water inlet } \\
\text { temperature of the heat source }\end{array}$ \\
\hline $\begin{array}{l}\text { Multi-unit heat } \\
\text { source control }\end{array}$ & $\begin{array}{l}\text { Multi-unit control of two heat sources observing } \\
\text { amount of heat obtained from states of return } \\
\text { header inlet and feed header outlet }\end{array}$ \\
\hline
\end{tabular}

[Absorption chiller/heater]
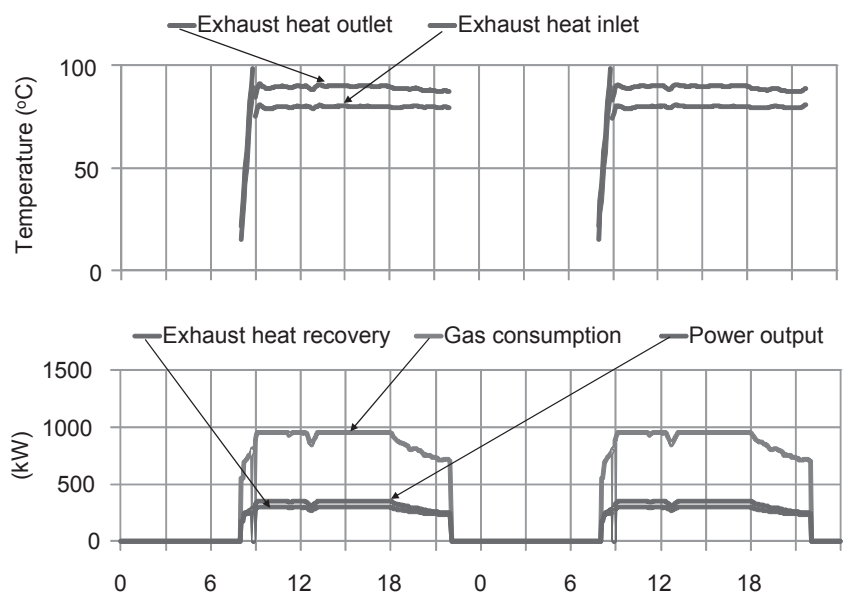

Fig. 12 Example of cogeneration system simulation results for typical summer days in Japan 
Confirmation of the heat balance of the exhaust heat system was conducted over a two-month summer period in order to verify the validity of the forward method used for the system simulation. Results showed the difference between the exhaust heat recovery of the gas engine and demand (equal to the sum of the exhaust heat recovery of the waste heat using absorption chiller-heater and the amount remaining unused) to be around $3 \%$, which is mainly because of using the immediately past time temperature of the water in the inlet pipes of the equipments in the simulation. Taking the time difference of 5 minutes into account, this imbalance is practically acceptable range.

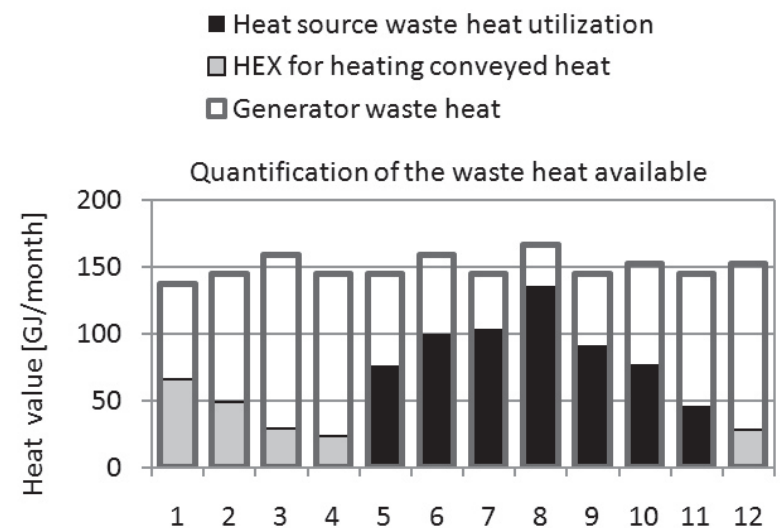

Fig. 13 Example of waste heat balance per month through a year

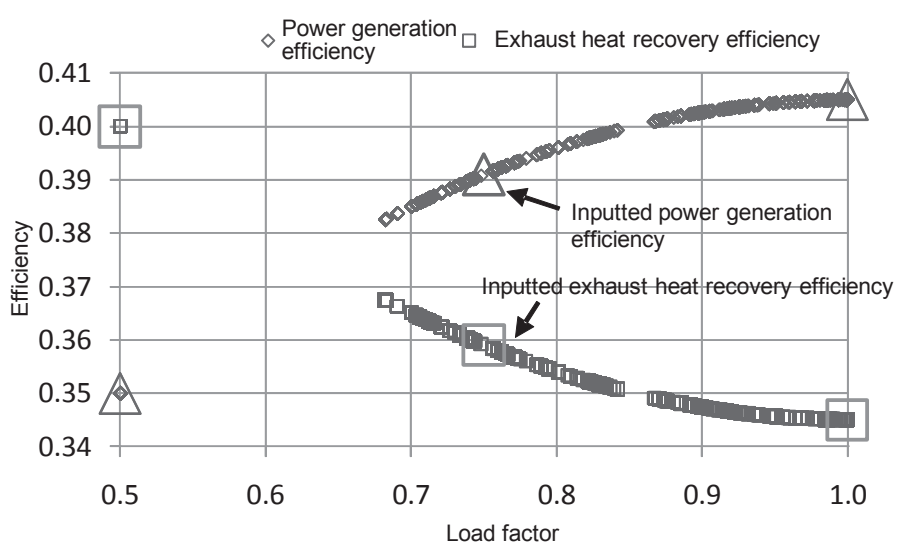

Fig. 14 Relationship between gas engine load factor and efficiency of power generation, and exhaust heat recovery (during two months of July and August)

This is due to the use of the forward method; for although the circulation of exhaust heat should cause the system temperature to gradually rise after the five-minute time interval used for calculations, the forward method allows exhaust heat to circulate only once during the simulation at the time concerned. It also treats the exhaust heat of the gas engine as theoretically being entirely stored in the pipes that are the system's heat carrier. Another reason for this is that the stability conditions between exhaust heat recovery and pipe heat capacity are disregarded. Although the integrated error for the period is around $3 \%$ as noted above, the above factors may give rise to errors that can no longer be ignored when frequency of operation increases, and this will need to continue to be verified in the future.

\section{Conclusions}

The computational model for facilities and equipment was determined on the basis of existing models and interviews with manufacturers. When calculations were performed with these connected, a problem was found to occur in the form of a heat imbalance due to the size of the circulation flow rate and the heat capacity to be absorbed. This will have to be dealt with by such means as modifying the order of calculations and adopting realistic flow rates. The system heat balance is generally good, and the indications are that a method of system simulation by means of a simple method of calculation has been successfully developed. The following points to enable simulations to be performed in a more versatile manner.

\section{(1) Expansion of components}

Actual buildings often employ a greater range of heat source devices that operate under multi-unit control. It is therefore necessary to create an environment in which system simulations for entire buildings can be performed by expanding the range of heat source devices and components of air systems.

(2) Improvement of versatility

The algorithm employed in this study was a simple forward method. As the results of calculations using this method can differ considerably depending on the order of calculations for facilities and equipment, a method of sequencing calculations more robustly or a switch to an algorithm for performing simple convergences (if versatility is to be raised) will be required.

\section{Acknowledgement}

This paper is one outcome of the work of the Cogeneration Study SWG (led by Professor Takashi Akimoto of the Shibaura Institute of Technology) of the BEST Development and Promotion Forum (chaired by Shuzo Murakami, Director of the Building Research Institute), which was established jointly by the Government and representatives of industry, and academia in the Japan Sustainable Building Consortium. The authors gratefully acknowledge the support of everyone involved. The members of the Cogeneration Study SWG:

Group Leader: Takashi Akimoto (Shibaura Institute of Technology), Deputy Group Leader: Kenichi Sasajima (Nihon Sekkei), Members: Fumio Nohara, Hiroshi Ninomiya, and Yasuhiro Tabata (all of Nikken Sekkei), Kyoichiro Konno (Yanmar Energy Systems), Makoto Satoh (Satoh Energy Research), and Ryota Kuzuki (Tokyo Gas), Secretariat: Kiyohisa Oine (Japan Sustainable Building Consortium) 


\section{References}

1) CASCADE III program for assessment of cogeneration systems using city gas, Society of Heating, Air-Conditioning and Sanitary Engineers of Japan, 2003 (written in Japanese)

2) Nagai Tatsuo, et. al.: Study on Simulation Time Intervals for a system simulation in a Building Energy and Environment Simulation Tool, the BEST, Architecture Institute of Japan Conference Collected Papers, September 2010, pp.1285-1288 (written in Japanese)

3) The Japan Institute of Energy: Cogeneration Plan and Design Manual 2005, Japan Industrial Publishing Co., Ltd., April 2005 (written in Japanese)

4) Program release and briefing materials for the first meeting of the BEST Development and Promotion Forum, Institute for Building Environment and Energy Conservation, March 2008 (written in Japanese)

5) Takashi Akimoto et al.: Development of an Integrated Energy Simulation Tool for Buildings and MEP Systems, the BEST Part 34, Outline of the Program for Cogeneration Systems, Society of Heating, Air-Conditioning and Sanitary Engineers of Japan Conference Collected Papers, August 2008, pp.1137-1140 (written in Japanese).

6) Makoto Satoh et al.: Development of an Integrated Energy Simulation Tool for Buildings and MEP Systems, the BEST Part 56, Characteristics of the Program for Cogeneration Systems, Society of Heating, Air-Conditioning and Sanitary Engineers of Japan Conference Collected Papers, September 2009, pp.707-710 (written in Japanese)

\section{和文要約}

\section{1. はじめに}

民生部門における低炭素化対策は喫緊の課題であり、特に建築分 野は、需要側の対策としてエネルギー利用の高度化が求められてい る。コージェネレーションシステムや太陽熱利用など、オンサイト で生成する熱を多段階に有効利用するシステムでは、適切に計画、 運用することにより大幅な低炭素化に貢献する技術として期待され る。システムの性能は、電力需要量と冷温熱需要量（以下、熱電需 要量と呼ぶ）のバランスや発生時刻にも影響される。この効果を定 量的に評価するためには、建築や空調、衛生、電気の各種設備の熱 電需要との連成計算が求められる。

これを可能にするシミュレーションプログラムとして、我が国で は躯体と設備を統合的に扱い、建築物総体としてエネルギー性能を 評価するシミュレーションツール（BEST: Building Energy Simulation Tool）の開発が国土交通省主導で進められている。 本研究では、BESTにおいてコージェネレーションを含むシステム の連成計算を可能とするモデルの構築を目的とする。

\section{2. 既存のシミュレーションプログラム CASCADEIII との比較} コージェネレーションシステム設計・評価用プログラムとして知 られている CASCADEIII と、BEST で求められる仕様とでは熱収支 の表現が異なる。BEST では熱媒の流量と温度差で表現されること、 ならびに 5 分程度の短い間隔での計算に対応する必要がある。

\section{3. 主な構成要素のモデル}

\section{(1) 発電機}

発電機のモデルについては機器仕様はカタログや技術資料に記載 された定格効率に加え、代表 2 点の部分負荷時（75\%、50\%）の効率 も用い、部分負荷特性曲線（二次曲線）に基づき、発電量に応じ、 ガス消費量と排熱利用量を求める。

\section{(2) コントローラ}

コントローラについては、出力一定制御の場合は「発電目標量＝ 対象発電機の定格発電」として、制御対象発電機に制御信号を送る。 一方、電力負荷追従制御の場合は、別途発電目標量を求め、制御対 象発電機に制御信号を送ることとした。

\section{（3）排熱投入型吸収冷温水機}

排熱投入型吸収冷温水機については、コントローラから冷水需要
量が与えられ、この需要量と排熱のポテンシャル（排熱入口温度、 排熱流量）によって排熱回収量を算出する。排熱回収量の計算は、 各系統の入口温度、流量から排熱回収可能量を算出する。これをも とに排熱出口温度をチェックし、最終的な排熱回収量を算出する。

ガス消費量については、排熱がなく直焚吸収冷温水機として運転 された時に消費されるガス量から、排熱利用分を差し引いて求める。 ある程度の低負荷運転時には排熱のみによって冷水を発生するが、 負荷率が高くなると排熱回収量を減じていき徐々にガス焚き増し量 を増加させていく特徴も再現するモデルとした。

\section{4. 連成計算}

サンプルシステムを対象とした運転シミュレーションを行った。

(1) サンプルシステム

中規模事務所ビルを対象とし、コージェネレーションシステムの 発電時の排熱を多段階利用するケースを設定した。発電機にはガス エンジンを用い、約 $90^{\circ} \mathrm{C}$ の温水排熱を排熱投入型吸収泠温水機で利 用する。

（2）シミュレーション結果

ガスエンジンは電力負荷追従運転を設定した。ガスエンジンの排 熱出入口温度から、夜間のシステム停止中に系の熱容量体である配 管の温度が外気温度程度まで低下し、冷却された排熱温水がガスエ ンジンに流入している状態が再現されている。

排熱投入型吸収冷温水機はガスエンジンの運転直後は排熱系の温 度が低いことから排熱は用いず、ガスの直焚き運転を行っている。

夏期 2 ケ月間についてガスエンジンの運転時における負荷率と発 電効率、排熱回収効率の関係を見ると、発電効率、排熱回収効率の いずれにおいても各部分負荷時の効率を二次補間した特性曲線に沿 った変化をしていることを確認できた。

夏期 2 カ月間の排熱系統の熱収支を確認したところ、ガスエンジ ンの排熱回収量と需要量（排熱投入型吸収冷温水機の排熱回収量と 未利用分との合計值）との差は $3 \%$ 程度であり、実用上支障の無い範 囲であった。運転回数が多くなってくると無視できない誤差を生じ る可能性があるので今後も継続して確認する必要がある。

\section{5. 結論}

本研究で構成したモデルは、既存の計算モデルやメーカーへのヒ 
アリングに基づき特性を決めているが、これらを接続した状態での 試算結果から、循環流量と吸収させる熱容量の大きさによっては、 熱収支がずれるという問題があることがわかった。これについては、 計算順序の工夫や、現実的な流量にするなどの対処法が必要と考え られる。概ね系の熱収支も良好であり、簡易な計算法で可能なシス テムシミュレーションの方法が構築できたと考える。

今後さらに汎用的なシミュレーションを行うにあたっては、以下 のような点について検討が必要である。

\section{(1) 設備機器の拡充}

実際の建物では複数の熱源機などが台数制御によって動作する場 合が多い。そのため、熱源機の拡充や空気系統の機器の拡充によっ
て、建物全体のシステムシミュレーションを行うような環境が必要 になる。

\section{（2）汎用性の向上}

今回のアルゴリズムには、簡易な「前進法」を採用した。「前進 法」の場合、設備機器の計算順序によって、計算結果が大きく異な ることが予想されるため、堅牢な計算順序の決定法、もしくはより 汎用性を高めるのであれば、簡易な収束を行うアルゴリズムへの変 更なども必要と考えられる。

（2010年 7 月30日原稿受理，2011年 1 月13日採用決定） 